\title{
Difficulties in implementing 21st century skills competence in vocational education learning
}

Farid Mutohhari ${ }^{1}$, S. Sutiman ${ }^{2}$, Muhammad Nurtanto ${ }^{3}$, Nur Kholifah ${ }^{4}$, Achmad Samsudin ${ }^{5}$

${ }^{1}$ Postgraduate Program, Technology and Vocational Education, Yogyakarta State University, Yogyakarta, Indonesia

${ }^{2}$ Department of Automotive Engineering Education, Yogyakarta State University, Yogyakarta, Indonesia

${ }^{3}$ Department of Mechanical Engineering Education, Universitas Sultan Ageng Tirtayasa, Serang, Banten, Indonesia

${ }^{4}$ Department of Culinary and Fashion Education, Yogyakarta State University, Yogyakarta, Indonesia

${ }^{5}$ Program of Physics Education, Universitas Pendidikan Indonesia, Bandung, Indonesia

\section{Article Info \\ Article history: \\ Received Apr 16, 2021 \\ Revised Aug 28, 2021 \\ Accepted Sep 9, 2021 \\ Keywords: \\ Communication skills \\ Creativity skill \\ Critical thinking \\ Collaboration \\ Digital literacy \\ Learning difficulties}

\begin{abstract}
The 21 st century learning requires complex competencies, transformations of technology-based learning and non-cognitive skills need. This situation makes it difficult for teachers of Indonesian vocational education apply $21 \mathrm{st}$ century skills. This study aimed to analyze the level of difficulty of teachers and students in vocational education and analyzing the differences in the difficulties faced in vocational education. This research used survey research with a quantitative approach. A total of 178 people participated in the study consisting of two public vocational high schools and two private vocational schools with the distribution of respondents consisting of 155 students and 23 teachers. Collecting data using a questionnaire in the form of a statement of difficulties faced by teachers and students, including creativity skills, critical thinking, problem solving, communication, collaboration, and digital literacy or information and communication technology (ICT) as many as 50 items. The instrument used was a Likert scale with very difficult, difficult, easy, and very easy categories. The findings of the study showed: i) All skills were identified on the "easy" criteria; and ii) There were significant differences between the difficulties faced by teachers and students, especially communication skills. The recommendation in this study is the need to improve 21 st century skills to produce competitive graduate candidates in vocational education.
\end{abstract}

This is an open access article under the CC BY-SA license.

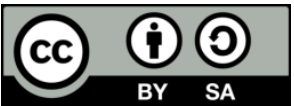

\section{Corresponding Author:}

Farid Mutohhari

Department of Technology and Vocational Education, Postgraduate Program

Yogyakarta State University

Sleman, Daerah Istimewa Yogyakarta 55281, Indonesia

Email: faridmutohhari.2020@student.uny.ac.id

\section{INTRODUCTION}

The essence of vocational education is to equip students' work competencies through learning [1], [2]. The work competencies of students who must be taught are oriented towards cognitive, affective, and psychomotor competencies. Vocational education can be called successful if all three competencies can be achieved properly [3]. However, the pace of change that continues to occur because of globalization presents its own challenges for vocational education. Especially now that it has entered the 21 st century, where the characteristics of work are dominated by solving complex problems [4]. Jobs related to solving complex problems require critical thinking skills, creativity skills supported by collaboration skills, and increasingly high digital literacy skills [5], [6]. 
As a sustainability learning, vocational education is very important to develop the competence of the 21 st century students [7]. The competence of solving complex and meaningful problems must be immediately taught to students in learning. Problem-based learning is an activity that focuses problems as a learning center to be studied and solved in depth [8]-[10]. In addition, the quality of problems and solutions is also given priority, so that the meaningfulness of learning is obtained by students [5]. The depth and meaningfulness of problem-solving based learning is influenced by several factors. Competence to think critically and creatively in solving problems is an important factor. Criticality and creativity will open a broad and deep view of the mind in collecting data as material for problem solving [11], [12].

Students' critical thinking and creativity in problem solving in learning also need to be supported by several factors. The ability to collaborate, communicate, and digital literacy are crucial factors that need attention [13]-[15]. The ability to collaborate and communicate will open, broad horizons for students to be able to exchange ideas and thoughts [5]. Then, digital literacy will play a role in equipping students with a comprehensive understanding of technology and digital media for learning [16]. A comprehensive understanding of technology and digital media will equip students' abilities in finding various digital learning resources that are relevant and broad to gather information. Thus, criticality and creativity in problem solving in learning will be reflected in students [17].

Several problems in learning on vocational education in Indonesia, including: i) Changing teacher habits in using conventional learning methods with a scientific approach; ii) Student-centered and passive learning habits [18]; iii) Interaction during learning in the form of collaboration and communication is very limited [19]; iv) The use of role technology in learning is limited and teachers as educators are very difficult [20]. Some of the problems that are the basis of students are student competencies. In addition, critical and creative abilities in solving problems are very limited. Thus, the role of teachers in learning must be strengthened by learning skills in the 21 st century.

The difficulties of transforming 21 st century technical and vocational education and training (TVET)-based learning must be resolved immediately. Conventional teacher-centered learning must be transformed with student-centered learning that emphasizes problem solving, critical thinking, creative thinking, collaboration, communication, and digital literacy. The level of difficulty experienced by teachers and students in implementing 21 st century competency-based learning needs to be analyzed in depth. Thus, this study will analyze the percentage level of difficulty of teachers and students in implementing problembased learning, critical thinking, creative, collaborative, communicative and digital literacy. In addition, this study will also analyze differences in the level of difficulty between teachers and students in managing and following 21 st century competency-based learning.

\section{RESEARCH METHOD}

This research was a survey research with a design developed by Rea and Parker [21]. The research approach used quantitative descriptors to describe the percentage of the difficulty level of 21st century competency-based learning. The study was conducted in four vocational schools in Sleman, Yogyakarta, Indonesia, with an automotive engineering expertise program. A total of 23 teachers and 155 students were involved in this study, who selected using probabilistic random sampling techniques. The research sample allocation is shown in Table 1.

Table 1. Participant distribution information data

\begin{tabular}{llcc}
\hline \multicolumn{1}{c}{ Name of schools } & Status & $\begin{array}{c}\text { Students } \\
\mathrm{n}(\%)\end{array}$ & $\begin{array}{c}\text { Teachers } \\
\mathrm{n}(\%)\end{array}$ \\
\hline SMK 1 Seyegan & Public school & $48(30.97)$ & $8(34.78)$ \\
SMK 1 Ngaglik & Public school & $40(25.81)$ & $6(26.09)$ \\
SMK Muhammadiyah Seyegan & Private school & $32(20.64)$ & $4(17.39)$ \\
SMK Diponegoro Depok & Private school & $35(22.58)$ & $5(21.74)$ \\
$\quad$ & & $155(100.00)$ & $23(100.00)$ \\
\hline
\end{tabular}

The data were collected using a closed questionnaire technique. The research instrument used a questionnaire totaling 50 statements with four answer options, namely: very difficult, difficult, easy, and very easy. The composition of the questionnaire instrument content is based on 21 st century skills indicators, which consist of problem-solving skills, critical thinking, creativity, collaboration, communication, and digital literacy. The following are indicators as instrument development shown in Table 2. 
Table 2. The 21st century learning skills aspects

\begin{tabular}{llcc}
\hline Learning skills aspect & \multicolumn{1}{c}{ Indicators } & Item & References \\
\hline Creativity & Creative thinking & 4 & [5], [10] \\
& Creative in collaborating & 4 & \\
& Implementing innovation & 2 & \\
Critical thinking & Effective reasoning & 3 & [22], [23] \\
& Systemic thinking & 3 & \\
& Complex assessment & 2 & \\
& Quality of decision making & 2 & \\
Problem-solving & The quality of the problem & 3 & [10], [22] \\
& Complexity of ways & 4 & \\
& Solution analysis skills & 3 & \\
Communication & Clarity of verbal articulation & 1 & [5], [23] \\
& Effectiveness in listening & 1 & \\
& Clarity of purpose of communicating & 1 & \\
& The use of ICT in communicating & 1 & \\
& Flexible compromises & 1 & \\
Collaboration & Collaborative work responsibilities & 1 & [22], [24] \\
& Efficiency of use & 2 & \\
Digital literacy & Effectiveness of use & 2 & \\
& Understanding of purpose \& benefits & 5 & [7], [25] \\
& Understanding of digital ethics & 5 & \\
\hline
\end{tabular}

The collected data were analyzed using descriptive statistics to describe the percentage of the difficulty level of implementing 21st century competency-based learning, one-way ANOVA to find out the difference in the level of difficulty between skills and the independent sample t-test to determine the differences in the level of difficulty experienced by teachers and students. The interpretation criteria by comparing the average score with categories refer to the opinions of Mardapi [26] as shown in Table 3.

Table 3. Criteria for average results

\begin{tabular}{cccc}
\hline \multirow{2}{*}{ Formula } & Interval score of learning skills & \multirow{2}{*}{ Category } \\
& $\mathrm{Cv}, \mathrm{CT}, \mathrm{PS}, \mathrm{DL}$ & $\mathrm{Cm}, \mathrm{Cb}$ & \multirow{2}{*}{. } \\
\hline$M i+1,5 S D i \leq M \leq M i+3,0 S D i$ & $32.5-40.0$ & $16.25-20.0$ & Very difficult \\
$M i+0 S D i \leq M \leq M i+1,5 S D i$ & $25.0-32.5$ & $12.5-16.25$ & Difficult \\
$M i-1,5 S D i \leq M \leq M i+0 S D i$ & $17.5-25.0$ & $8.75-12.5$ & Easy \\
$M i-3,0 S D i \leq M \leq M i-1,5 S D i$ & $10.0-17.5$ & $5.0-8.75$ & Very easy \\
\hline
\end{tabular}

\section{RESULTS}

Learning orientation that emphasizes the 21 st century skills of students is still classified as not fully applicable. In addition, students in following these lessons also still experience difficulties. The level of difficulty experienced by teachers and students still exceeds the percentage of $50 \%$. Only digital literacy students who have a percentage below 50\%. A descriptive analysis of the difficulty data in the application of 21 st century skills-based learning is shown in Table 4.

Table 4. Difficulty of 21 st century skills

\begin{tabular}{|c|c|c|c|c|c|c|c|c|c|c|}
\hline Learning skills aspect & Item & Difficulty & Mean & Percentage & Median & Mode & Std. Dev & Min & Max & Category \\
\hline \multirow{2}{*}{ Creativity skills } & \multirow{2}{*}{10} & Teachers & 21.87 & $54.67 \%$ & 22.00 & 20 & 3.721 & 14 & 28 & Easy \\
\hline & & Students & 23.05 & $57.61 \%$ & 24.00 & 20 & 2.678 & 18 & 29 & Easy \\
\hline \multirow{2}{*}{ Critical thinking skills } & \multirow{2}{*}{10} & Teachers & 22.70 & $56.74 \%$ & 23.00 & 20 & 4.456 & 14 & 30 & Easy \\
\hline & & Students & 24.23 & $60.56 \%$ & 24.00 & 22 & 3.480 & 18 & 37 & Easy \\
\hline \multirow{2}{*}{ Problem solving skills } & \multirow{2}{*}{10} & Teachers & 24.48 & $61.20 \%$ & 25.00 & 27 & 4.111 & 16 & 32 & Easy \\
\hline & & Students & 24.69 & $62.56 \%$ & 25.00 & 25 & 3.366 & 18 & 37 & Easy \\
\hline \multirow{2}{*}{ Communication skills } & \multirow{2}{*}{5} & Teachers & 9.74 & $48.70 \%$ & 10.00 & 10 & 1.815 & 7 & 13 & Easy \\
\hline & & Students & 10.62 & $53.10 \%$ & 10.00 & 10 & 1.330 & 8 & 13 & Easy \\
\hline \multirow{2}{*}{ Collaboration skills } & \multirow{2}{*}{5} & Teachers & 10.30 & $51.52 \%$ & 10.00 & 10 & 1.636 & 7 & 14 & Easy \\
\hline & & Students & 10.83 & $54.16 \%$ & 11.00 & 10 & 1.697 & 7 & 15 & Easy \\
\hline \multirow{2}{*}{ Digital literacy skills } & \multirow{2}{*}{10} & Teachers & 20.13 & $50.33 \%$ & 20.00 & 21 & 2.849 & 14 & 25 & Easy \\
\hline & & Students & 19.97 & $49.93 \%$ & 20.00 & 20 & 2.974 & 14 & 26 & Easy \\
\hline
\end{tabular}

From these data, information is obtained that the application of 21 st century skills-based learning is included in the "easy" category for all skills. However, both students and teachers still experience considerable difficulties in implementing the learning. The highest level of difficulty experienced by teachers 
and students is related to the application of learning that is oriented towards problem solving skills. Meanwhile, digital literacy is a skill possessed by both teachers and students with the lowest level of difficulty. The results of the percentage level of difficulty were then analyzed for the difference in the level of difficulty between each skill, both those possessed by teachers and students. One way ANOVA testing on 21 st century skills possessed by teachers with df (23) obtained an F value of 4.760 and a p-value of 0.046 $(0.046<0.050)$. It was concluded that there were significant differences in difficulty between several skills. Likewise, the results of the analysis of students with df (155) obtained an F value of 4.020 and a p-value of $0.048(0.048<0.050)$. It was concluded that there were also significant differences in difficulty between several skills. After that, to find out which skills have different levels of difficulty, a post hoc test is carried out using the Tukey method. Table 5 presents the different levels of difficulty of each 21 st century skill.

Table 5 . The difference in difficulty level between 21 st century skills

\begin{tabular}{|c|c|c|c|c|c|c|c|}
\hline \multirow{2}{*}{\multicolumn{2}{|c|}{ Learning skills aspect }} & \multicolumn{2}{|c|}{$\operatorname{Diff}(\%)$} & \multicolumn{2}{|c|}{ Sig } & \multicolumn{2}{|c|}{ Decision } \\
\hline & & Teachers & Students & Teachers & Students & Teachers & Students \\
\hline \multirow{5}{*}{ Creativity } & Critical thinking & -2.070 & -2.950 & 0.412 & 0.336 & No different & No different \\
\hline & Problem solving & -6.530 & -4.950 & 0.138 & 0.186 & No different & No different \\
\hline & Communication & 5.970 & 4.510 & 0.156 & 0.195 & No different & No different \\
\hline & Collaboration & 3.150 & 3.450 & 0.302 & 0.287 & No different & No different \\
\hline & Digital literacy & 4.340 & 7.680 & 0.211 & 0.080 & No different & No different \\
\hline \multirow{5}{*}{ Critical thinking } & Creativity & 2.070 & 2.950 & 0.412 & 0.326 & No different & No different \\
\hline & Problem solving & -4.460 & -2.000 & 0.198 & 0.400 & No different & No different \\
\hline & Communication & 8.040 & 7.460 & 0.068 & 0.088 & No different & No different \\
\hline & Collaboration & 5.220 & 6.400 & 0.170 & 0.144 & No different & No different \\
\hline & Digital literacy & 6.410 & 10.630 & 0.143 & 0.031 & No different & Different \\
\hline \multirow{5}{*}{ Problem solving } & Creativity & 6.530 & 4.950 & 0.138 & 0.186 & No different & No different \\
\hline & Critical thinking & 4.460 & 2.000 & 0.198 & 0.400 & No different & No different \\
\hline & Communication & 12.500 & 9.460 & 0.022 & 0.046 & Different & Different \\
\hline & Collaboration & 9.680 & 8.400 & 0.038 & 0.056 & Different & No different \\
\hline & Digital literacy & 10.870 & 12.630 & 0.032 & 0.019 & Different & Different \\
\hline \multirow{5}{*}{ Communication } & Creativity & -5.970 & -4.510 & 0.156 & 0.195 & No different & No different \\
\hline & Critical thinking & -8.040 & -7.460 & 0.068 & 0.088 & No different & No different \\
\hline & Problem solving & -12.500 & -9.460 & 0.022 & 0.046 & Different & Different \\
\hline & Collaboration & -2.820 & -1.060 & 0.341 & 0.598 & No different & No different \\
\hline & Digital literacy & -1.630 & 3.170 & 0.571 & 0.300 & No different & No different \\
\hline \multirow{5}{*}{ Collaboration } & Creativity & -3.150 & -3.450 & 0.302 & 0.287 & No different & No different \\
\hline & Critical thinking & -5.220 & -6.400 & 0.170 & 0.144 & No different & No different \\
\hline & Problem solving & -9.680 & -8.400 & 0.038 & 0.056 & Different & No different \\
\hline & Communication & 2.820 & 1.060 & 0.341 & 0.598 & No different & No different \\
\hline & Digital literacy & 1.190 & 4.230 & 0.590 & 0.212 & No different & No different \\
\hline \multirow{5}{*}{ Digital literacy } & Creativity & -4.340 & -7.680 & 0.211 & 0.080 & No different & No different \\
\hline & Critical thinking & -6.410 & -10.630 & 0.143 & 0.031 & No different & Different \\
\hline & Problem solving & -10.870 & -12.630 & 0.032 & 0.019 & Different & Different \\
\hline & Communication & 1.630 & -3.170 & 0.571 & 0.300 & No different & No different \\
\hline & Collaboration & -1.190 & -4.230 & 0.590 & 0.212 & No different & No different \\
\hline
\end{tabular}

After knowing the difference in difficulty level between 21 st century skills, the independent sample t-test was then carried out to determine the differences in the difficulties experienced by teachers and students. Table 6 presents the results of the independent sample t-test obtained. The difficulties faced by teachers and students in implementing 21st century skills-based learning tend to have no significant differences in most aspects. Only the communication skills between teachers and students differ significantly in level of difficulty. In effective and efficient communication, students have more difficulty in applying it to learning than teachers. Figure 1 explains the different levels of difficulty in implementing 21 st century skillsbased learning that students and teachers have.

Table 6. The level difference of difficulty between teachers and students

\begin{tabular}{ccccccc}
\hline Variable & Df & Mean different & t-values & t-table & Sig. & Decision \\
\hline Creativity skills & 176 & -1.18 & -1.859 & 1.973 & 0.065 & No different \\
Critical thinking skills & 176 & -1.53 & -1.893 & 1.973 & 0.060 & No different \\
Problem solving skills & 176 & -0.21 & -748 & 1.973 & 0.455 & No different \\
Communication skills & 176 & -0.88 & -2.814 & 1.973 & 0.005 & Different \\
Collaboration skills & 176 & -0.53 & -1.398 & 1.973 & 0.164 & No Different \\
Digital literacy skills & 176 & 0.16 & 0.236 & 1.973 & 0.813 & No Different \\
\hline
\end{tabular}




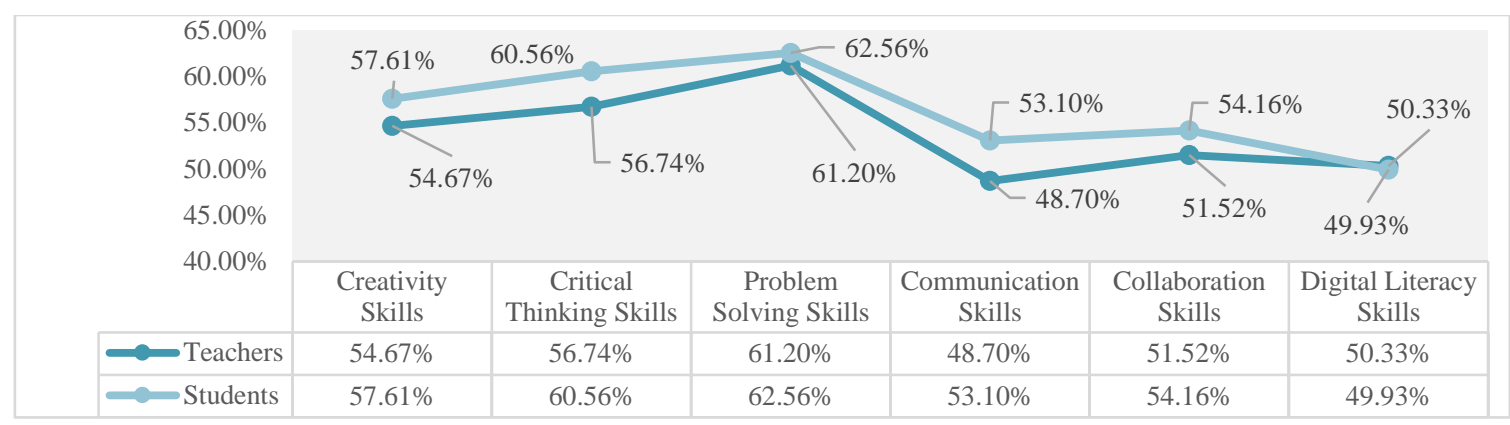

Figure 1. Different levels of difficulty in implementing 21st century skills-based learning

\section{DISCUSSION}

Creativity in doing work is very important to be developed at this time. Through learning, creativity must be sought to be shaped and matured [27]. Learning creativity is very important to be a provision for students when they graduate, in doing work that is constantly changing. Creativity is also very important to support activities that are complex problem solving [12]. Creativity plays a role in providing a stimulus to find new ideas through comprehensive thinking and search [28]. Thus, it is very important for vocational education to organize learning to develop critical thinking skills in students. Vocational education teachers and students are still not maximal in implementing learning-oriented creativity skills. Guidance by related educational elements is very important to develop skills in managing this ability-based learning. The application of technology, models and learning media based on the 21 st century is one of the important keys in developing this capability [17], [29]. In addition, the formation of a creative and innovative learning environment is an important key in developing creativity in both teachers and students [30].

Critical thinking is one of the competencies that must be possessed in the 21st century and the era of the industrial revolution 4.0 [31], [32]. Criticism is an important provision in carrying out increasingly complex jobs. Applying critical thinking skills to work will get results that have high meaning and benefits [33]. In addition, critical thinking skills will help in problem-solving-oriented activities [34]. The inability of vocational education in Indonesia to implement learning based on critical thinking skills as a whole must be of particular concern to all elements of education. In this context, teachers need training and guidance to maximize the management of competency-based learning. In addition, students also need provision on how to follow learning steps that are oriented towards critical thinking skills. One of the effective ways to improve critical thinking skills is to apply learning based on problem-solving abilities [35].

Problem solving is an important aspect that must be fully mastered by students. The more complex the problems in life, the higher the ability to solve them [36]. In the context of learning, problem-solving abilities will affect student motivation in learning [37]. Problem-based learning can also improve student learning outcomes [38]. The ability to solve problems at this time is very important for vocational education students to have as a provision to enter the world of work. Disruption of work, competence and technology demands the role of problem-solving abilities to solve job problems [4]. Adaptive to developments that disrupt work and replace with new ones characterizes the workforce having a good ability to solve problems [39]. In addition, a person cannot be separated from problems in everyday life that are increasingly complex, requiring problem-solving abilities to solve them [40].

The inability of teachers and students to apply problem-solving based learning can hinder the achievement of current competency needs. The ability to think critically and creatively will be difficult to form. In addition, student learning outcomes will tend to stagnate or even decrease as motivation to learn also decreases [37]. Thus, it is very important to carry out constructivist-based guidance and direction to carry out problem-solving based learning [41]. Development of creative and critical thinking skills in problem solving for teachers and students is an effort that can be done [42]. In addition, the practicality and effectiveness of problem-solving oriented learning approaches must continue to be developed [43].

Clear and precise communication is an important ability to be applied in learning. A good communication culture is very important to get used to provide provisions for students to do jobs that currently require communication skills [5], [32]. Good communication will be useful for improving students' learning experiences [44]. In addition, the ability to communicate with the right articulation can support students in increasing creativity and critical thinking in learning [41], [45]. The results of the analysis concluded that the students' difficulties were higher with a significant difference from the difficulties experienced by the teacher. This means that students have more difficulty following learning that is oriented towards communication skills than the teacher. The higher difficulty of students indicates that it is necessary to transform learning which can emphasize the fluency of students in communicating. 
Teachers as learning managers can apply various interactive digital media to improve students' communication skills [17]. However, although teachers and students have significantly different levels of difficulty, both have the highest difficulty level on the same indicator. Based on the statement items in the research instrument, it is known that teachers and students have the highest difficulty in their ability to communicate between the diversity of students. Diversity in the learning environment is a crucial factor that must be managed appropriately because it can affect teacher-student or student-to-student communication [46]. The role of all elements of education, including the principal, must be in solving this problem [47]. Selfefficacy, emotional intelligence, and empathy for attitudes towards the right to diversity must be cultivated in teachers and students to overcome problems in communication [48].

The ability to collaborate is an important aspect that students must master at this time in learning and work [32]. Work in the 21st century emphasizes collaboration between individuals, teams and the world of work [5]. Collaboration also has an important role in improving students' abilities [49]. In addition, collaboration is important to support critical and creative thinking skills in solving problems [14], [28]. The difficulties of teachers and students in applying learning that emphasizes collaboration must be solved. Guidance for teachers and students is very important. One way to encourage the application of collaboration in learning is by providing training related to interactive learning displays or designs using appropriate technology and media in accordance with 21 st century developments [50]. In addition, the integration of digital technology that is integrated into STEM learning can also improve collaboration skills [17], [51].

Digital literacy is a comprehensive understanding and ability to assess and use digital technology based on its benefits and uses [16]. Digital literacy is one of the competencies needs in the 21 st century and the 4.0 industrial revolution [52]. Digital literacy serves as the basis for establishing capability in using digital technology [13]. In addition, digital literacy and digital skills are also useful to help improve critical and creative thinking and problem solving. Thus, digital literacy is very important to be applied in learning, especially in vocational education [17]. The difficulties of vocational teachers and students in applying and participating in learning that emphasizes the formation of digital literacy are influenced by several factors. The ability to provide minimal digital facilities and infrastructure is one of the reasons [52]. In addition, the ability of teachers and students to understand and choose digital technology and digital learning resources is also a crucial factor [17]. Thus, it is very important for vocational education to meet the standards of digital infrastructure and provide training to teachers and students.

\section{CONCLUSION}

Based on the results and discussion, it can be concluded that: i) All 21st century skills that have difficulty being applied by teachers and students consisting of creativity, critical thinking, problem solving, communication, collaboration and digital literacy fall into the easy category; and ii) Significant differences in the level of difficulty experienced by teachers and students occur in communication skills. Students have more difficulty in implementing learning-oriented communication skills. This indicates that students need more intensive attention and improvement in communication. However, both teachers and students have average scores and percentages that indicate the application of 21 st century skill-based learning has not been maximal. Various efforts, such as training and developing the competence of teachers and students in implementing 21 st century skill-based learning, need to be improved.

\section{REFERENCES}

[1] L. Clark and C. Winch, Vocational Education: International Approaches, Developments and Systems. New York: Routledge, 2007.

[2] S. Billett, Vocational Education: Purposes, Traditions and Prospects. Dordrecht: Springer, 2011.

[3] Z. Arifin, M. Nurtanto, W. Warju, R. Rabiman, and N. Kholifah, "The TAWOCK conceptual model at content knowledge for professional teaching in vocational education," International Journal of Evaluation and Research in Education (IJERE), vol. 9, no. 3, pp. 697-703 2020, doi: 10.11591/ijere.v9i3.20561.

[4] T. Iñiguez-Berrozpe and E. Boeren, "Twenty-First Century Skills for All: Adults and Problem Solving in Technology Rich Environments," Technology, Knowledge and Learning, vol. 25, no. 4, pp. 929-951, 2020, doi: 10.1007/s10758-019-09403-y.

[5] B. Trilling and C. Fadel, 21st Century Skills: Learning for Life in Our Times. San Francisco: Jossey-Bass, 2009.

[6] R. S. Malik, "Educational Challenges in 21st Century and Sutainable Development," Journal of Sustainable Development Education and Research, vol. 2, no. 1, pp. 9-20, 2018, doi: 10.17509/jsder.v2i1.12266.

[7] M. Pavlova, Technology and Vocational Education for Sustainable Development. Queensland: Springer Science Business Media B.V., 2009.

[8] D. H. Jonassen, Leraning to Solve Problems: A Handbook for Designing Problem-Solving Learning Environments. New York: Routledge, 2011. 
[9] M. Nurtanto, H. Sofyan, P. Pardjono, and S. Suyitno, "Development model for competency improvement and national vocational qualification support frames in Automotive technology," International Journal of Evaluation and Research in Education (IJERE), vol. 9, no. 1, pp. 168-176, 2020, doi: 10.11591/ijere.v9i1.20447.

[10] O.-S. Tan, Problem Based Learning and Creativity. Singapore: Cengage Learning Asia Pte Ltd, 2009.

[11] M. F. Lee, S. N. M. Sohod, and A. Ab Rahman, "Exploring The Mastery Level of Critical Thinking and Problem Solving Skill among The Technical Undergraduate," Journal of Technical Education and Training, vol. 11, no. 3, pp. 9-14, 2019, doi: 10.30880/jtet.2019.11.03.002.

[12] M. Khalid, S. Saad, S. R. Abdul Hamid, M. Ridhuan Abdullah, H. Ibrahim, and M. Shahrill, "Enhancing creativity and problem solving skills through creative problem solving in teaching mathematics," Creativity Studies, vol. 13, no. 2, pp. 270-291, 2020, doi: 10.3846/cs.2020.11027.

[13] T. Frank and J. Castek, "From Digital Literacies to Digital Problem Solving: Expanding Technology-rich Learning Opportunities for Adults," Journal of Research and Practice for Adult Literacy, Secondary, and Basic Education, pp. 66-70, 2017.

[14] N. M. M. Dowell, Y. Lin, A. Godfrey, and C. Brooks, "Exploring The Relationship between Emergent Sociocognitive Roles, Collaborative Problem-Solving Skills, and Outcomes: A Group Communication Analysis," Journal of Learning Analytics, vol. 7, no. 1, pp. 38-57, 2020, doi: 10.18608/jla.2020.71.4.

[15] N. Nonthamand and J. N. Songkhla, "The Correlation of Open Learning, Collaboration, Learning Tools, and Creative Problem Solving by Graduate Students in Thailand," International Journal of Emerging Technologies in Learning, vol. 13, no. 9, pp. 280-289, 2018, doi: 10.3991/ijet.v13i09.7835.

[16] R. H. Jones and C. A. Hafner, Understanding Digital Literacies: A Practical Introduction. Routledge, 2012, doi: $10.4324 / 9780203095317$.

[17] D. R. Rizaldi, E. Nurhayati, and Z. Fatimah, "The Correlation of Digital Literation and STEM Integration to Improve Indonesian Students' Skills in 21st Century," International Journal of Asian Education, vol. 1, no. 2, pp. 73-80, 2020, doi: 10.46966/ijae.v1i2.36.

[18] M. Nurtanto, N. Kholifah, A. Masek, P. Sudira, and A. Samsudin, "Crucial Problems in Arranged The Lesson Plan of Vocational Teacher," International Journal of Evaluation and Research in Education (IJERE), vol. 10, no. 1, pp. 345-354, 2021, doi: 10.11591/ijere.v10i1.20604.

[19] M. N. Haq and M. Murdiono, "Teacher problems in implementing the scientific approach toward civics and citizenship education," (in Indonesia), Jurnal Civics: Media Kajian Kewarganegaraan, vol. 16, no. 2, pp. 165-176, 2019, doi: 10.21831/jc.v16i2.24603.

[20] E. Sawitri, M. S. Astiti, and Y. Fitriani, "Learning obstacles and challenges based on information and communication technology," (in Indonesia), Seminar Nasional Pendidikan Program Pascasarjana Universitas PGRI Palembang, 2019, pp. 202-213.

[21] L. M. Rea and R. A. Parker, Designing and Conducting Survey Research: A Comprehensive Guide, 4th ed. San Francisco: Jossey-Bass, 2014.

[22] B. Trilling and C. Fadel, 21st Century Skills: Learning for Life in Our Times, 1st ed. San Francisco: Calif: John Wiley and Sons Inc, 2012.

[23] E. Care, P. Griffin, and M. Wilson, Assessment and Teaching of 21st Century Skills: Research and Applications. New York: Springer International Publishing, 2018, doi: 10.1007/978-3-319-65368-6.

[24] E. van Laar, A. J. A. M. van Deursen, J. A. G. M. van Dijk, and J. de Haan, "The Relation between 21st-Century Skills and Digital skills: A Systematic Literature Review," Computers in Human Behavior, vol. 72, no. 12, pp. 577-588, 2017, doi: 10.1016/j.chb.2017.03.010.

[25] Organisation for Economic Cooperation and Development (OECD), 21st Century Technologies: Promises and Perils of a Dynamic Future. Paris: OECD Library, 1998. doi: 10.1787/9789264163539-en.

[26] D. Mardapi, Educational Measurement, Assessment and Evaluation, (in Indonesia). Yogyakarta: Mitra Cendekia Press, 2012.

[27] C. de la Peña Álvarez, "Importance of Creativity and Learning in Preservice Teachers," Electronic Journal of Research in Educational Psychology, vol. 17, no. 48, pp. 267-294, 2019, doi: 10.25115/ejrep.v17i48.2246.

[28] M. Ahmadifar, B. Saeidipour, M. R. Sarmadi, and M. Farajollahi, "Investigate Online Collaborative Learning Based on the Students Differences of Individual, to Enhance Creativity in Online Small Groups," Journal of Economic and Social Research, vol. 19, no. 1, pp. 18-26, 2020.

[29] M. Zare, R. Sarikhani, M. Salari, and V. Mansouri, "The Impact of E-Learning on University Students' Academic Achievement and Creativity," Journal of Technical Education and Training, vol. 8, no. 1, pp. 25-33, 2016, doi: 10.30880/jtet.2016.13.01.002.

[30] M. Fan and W. Cai, "How Does a Creative Learning Environment Foster Student Creativity? An Examination on Multiple Explanatory Mechanisms," Current Psychology, pp. 1-10, 2020, doi: 10.1007/s12144-020-00974-z.

[31] L. Stuchlikova, "Challenges of Education in The 21st Century," in ICETA 2016 - 14th IEEE International Conference on Emerging eLearning Technologies and Applications, Proceedings, 2016, pp. 335-340. doi: 10.1109/ICETA.2016.7802072.

[32] N. Salleh and S. Puteh, "A Review of the 21st Century Skills in Technical Vocational Education and Training (TVET)," Advanced Science Letters, vol. 23, no. 2, pp. 1225-1228, 2017, doi: 10.1166/asl.2017.7546.

[33] W. Wahyudi, S. B. Waluya, H. Suyitno, and I. Isnarto, "Schemata and Creative Thinking Ability in Cool-CriticalCreative-Meaningful (3CM) Learning," International Journal of Sustainability in Higher Education, vol. 22, no. 1, pp. 1-28, 2020, doi: 10.1108/IJSHE-06-2019-0198. 
[34] T. M. Sholihah and B. Lastariwati, "Problem Based Learning to Increase Competence of Critical Thinking and Problem Solving," Journal of Education and Learning (EduLearn), vol. 14, no. 1, pp. 148-154, 2020, doi: 10.11591/edulearn.v14i1.13772.

[35] Kardoyo, A. Nurkhin, Muhsin, and H. Pramusinto, "Problem-Based Learning Strategy: Its Impact on Students' Critical and Creative Thinking Skills," European Journal of Educational Research, vol. 9, no. 3, pp. 1141-1150, 2020, doi: 10.12973/EU-JER.9.3.1141.

[36] D. H. Jonassen, Learning to Solve Problems. San Francisco: Pfeiffer, 2004.

[37] A. U. Putri, L. Rusyati, and D. Rochintaniawati, "The Impact of Problem-Solving Model on Students' Concept Mastery and Motivation in Learning Heat Based on Gender," Journal of Science Learning, vol. 1, no. 2, pp. 71-76, 2018, doi: 10.17509/jsl.v1i2.9793.

[38] B. Murtiyasa and I. I. Al Karomah, "The Impact of Learning Strategy of Problem Solving and Discovery towards Learning Outcomes Reviewed from Students Learning Motivation," Universal Journal of Educational Research, vol. 8, no. 9, pp. 4105-4112, 2020, doi: 10.13189/ujer.2020.080936.

[39] P. K. Ross, S. Ressia, and E. J. Sander, Work in the 21 st Century. United Kingdom: Emerald Publishing, 2017, doi: $10.1108 / 9781787145771$

[40] S. C. Cheng, H. C. She, and L. Y. Huang, "The Impact of Problem-Solving Instruction on Middle School Students' Physical Science Learning: Interplays of Knowledge, Reasoning, and Problem Solving," Eurasia Journal of Mathematics, Science and Technology Education, vol. 14, no. 3, pp. 731-743, 2018, doi: 10.12973/ejmste/80902.

[41] S. Budi, H. Darmawan, and M. Saputro, "Analysis of mathematic communication ability to be reviewed from student learning creativity in statistical materials," Daya Matematis: Jurnal Inovasi Pendidikan Matematika, vol. 8, no. 1, pp. 161-166, 2020, doi: 10.26858/jds.v8i1.13325.

[42] Y. M. Heong, N. Hamdan, K. B. Ching, T. T. Kiong, and N. Azid, "Development of Integrated Creative and Critical Thinking Module in Problem-Based Learning to Solve Problems," International Journal of Scientific and Technology Research, vol. 9, no. 3, pp. 6567-6571, 2020.

[43] N. Akben, "Effects of the Problem-Posing Approach on Students' Problem Solving Skills and Metacognitive Awareness in Science Education," Research in Science Education, vol. 50, no. 3, pp. 1143-1165, 2020, doi: 10.1007/s11165-018-9726-7.

[44] L. Jolly and S. White, "Communication, Collaboration, and Enhancing the Learning Experience: Developing a Collaborative Virtual Enquiry Service in University Libraries in the North of England," New Review of Academic Librarianship, vol. 22, no. 2-3, pp. 176-191, 2016, doi: 10.1080/13614533.2016.1156002.

[45] C. Epçaçan, "A Review on The Relationship Between Critical Thinking Skills and Learning Domains of Turkish Language," Educational Research and Reviews, vol. 14, no. 3, pp. 67-77, 2019, doi: 10.5897/err2018.3658.

[46] J. Roksa, C. A. Kilgo, T. L. Trolian, E. T. Pascarella, C. Blaich, and K. S. Wise, "Engaging with Diversity: How Positive and Negative Diversity Interactions Influence Students' Cognitive Outcomes," Journal of Higher Education, vol. 88, no. 3, pp. 297-322, 2017, doi: 10.1080/00221546.2016.1271690.

[47] K. Pollock and P. Briscoe, "School principals' understandings of student difference and diversity and how these understandings influence their work," International Journal of Educational Management, vol. 34, no. 3, pp. 518-534, 2019, doi: 10.1108/IJEM-07-2019-0243.

[48] F. M. M. Rodríguez, R. R. Clares, and M. R. G. Muñoz, "Influence of Resilience, Everyday Stress, Self-Efficacy, Self-Esteem, Emotional Intelligence, And Empathy on Attitudes Toward Sexual and Gender Diversity Rights," International Journal of Environmental Research and Public Health, vol. 17, no. 17, pp. 1-21, 2020, doi: 10.3390/ijerph17176219.

[49] N. M. Fusco, et al., "Creating a Film to Teach Health Professions Students The Importance of Interprofessional Collaboration," American Journal of Pharmaceutical Education, vol. 84, no. 4, pp. 507-513, 2020, doi: 10.5688/ajpe7638.

[50] K. Sharma, I. Leftheriotis, and M. Giannakos, "Utilizing Interactive Surfaces to Enhance Learning, Collaboration and Engagement: Insights from Learners' Gaze and Speech,” Sensors (Switzerland), vol. 20, no. 7, pp. 1-27, 2020, doi: $10.3390 / \mathrm{s} 20071964$.

[51] N. Muhammad, P. Sudira, N. Kholifah, A. Samsudin, and W. Warju, "Vocational Teachers' Perceptions and Perspectives in the Implementation of STEM Learning in the 21 st Century," TEM Journal, vol. 9, no. 4, pp. 1665-1680, 2020, doi: 10.18421/TEM94-46.

[52] G. Falloon, "From digital literacy to digital competence: the teacher digital competency (TDC) framework," Educational Technology Research and Development, vol. 68, no. 5, pp. 2449-2472, 2020, doi: 10.1007/s11423020-09767-4. 